\title{
Hubungan Kecukupan Vitamin A, Vitamin C, Zink Dan Kadar Hemoglobin dengan Kesegaran Jasmani Siswa SMA Negeri 4 Semarang
}

\section{The Relation of Sufficiet Level of Vitamin A, Vitamin C, Zink and Hemoglobin Levels with Physical Fitness of Students in Senior High School 4 Semarang}

\author{
Fitria Nur Rakhmawati ${ }^{1}$, Setyo Prihatin ${ }^{2}$, Dyah Nur Subandriani ${ }^{3}$, \\ Ria Ambarwati ${ }^{4}$, M. Jaelani ${ }^{5}$ \\ ${ }^{1}$ Mahasiswa Program Studi D-IV Jurusan Gizi Poltekkes Kemenkes Semarang \\ 2,3, 4, 5 Dosen Jurusan Gizi Poltekkes Kemenkes Semarang
}

\begin{abstract}
Background : Physical fitness is the ability of a person's body to perform daily work tasks without causing significant fatigue. The importance of physical fitness for schoolchildren and adolescents, among others, can increase the ability of the body organs, social emotional, sportsmanship and spirit of composition. One of the factors that affect physical freshness is the hemoglobin level. Adequacy of vitamins and minerals is also a factor that indirectly affects physical fitness.
\end{abstract}

Objectives : Describe the relationship of sufficiency of vitamin A, vitamin C, zinc and hemoglobin levels with physical fitness students in Senior High School 4 Semarang.

Method : This research type is analytical descriptive with Cross Sectional design. The number of respondents is 104 students. Respondents were selected by proportional stratified sampling. Dependent variable of this research is physical fitness, independent variable that is vitamin A sufficiency, vitamin C sufficiency, zinc adequacy and hemoglobin level. Data analysis using Rank Spearman test and multiple linear regression test.

Results : There is a relationship between hemoglobin ( $p$-value $=0,000$ ) with physical fitness. There was no correlation between vitamin A adequacy ( $p$-value $=0,788)$, vitamin $C$ adequacy ( $p$-value $=0,203)$, adequacy of zinc ( $p$-value $=0,257$ ) with physical fitness.

Conclusion : Hemoglobin level is the most influential factor on physical fitness of Senior High School 4 Semarang students.

Keywords : physical freshness, vitamin a adequacy, vitamin c adequacy, zink adequacy, and hemoglobin levels

\section{ABSTRAK}

Latar Belakang : Kesegaran jasmani adalah kemampuan tubuh seseorang untuk melakukan tugas pekerjaan sehari-hari tanpa menimbulkan kelelahan yang berarti. Pentingnya kesegaran jasmani bagi anak sekolah dan remaja antara lain dapat meningkatkan kemampuan organ tubuh, sosial emosional, sportivitas dan semangat kompotisi. Salah satu faktor yang mempengaruhi kesegaran jasmani adalah kadar hemoglobin. Kecukupan vitamin dan mineral juga menjadi faktor yang secara tidak langsung mempengaruhi kesegaran jasmani.

Tujuan : Mendiskripsikan hubungan kecukupan vitamin A, vitamin C, zink dan kadar hemoglobin dengan kesegaran jasmani siswa SMA Negeri 4 Semarang.

Metode : Jenis penelitian ini adalah deskriptif analitik dengan rancangan Cross Sectional. Jumlah responden adalah 104 siswa. Responden dipilih dengan cara proportional stratified sampling. Variabel dependent penelitian ini adalah kesegaran jasmani, variabel independent yaitu kecukupan vitamin A, kecukupan vitamin $C$, kecukupan zink dan kadar hemoglobin. Analisis data menggunakan uji Rank Spearman dan uji Regresi Linier Ganda. 
Hasil: Ada hubungan antara kadar hemoglobin $(p-v a l u e=0,000)$ dengan kesegaran jasmani. Tidak ada hubungan antara kecukupan vitamin A ( $p$-value $=0,788)$, kecukupan vitamin $C(p$-value $=0,203)$, kecukupan zink ( $p$ value $=0,257$ ) dengan kesegaran jasmani.

Kesimpulan: Kadar hemoglobin merupakan faktor yang paling berpengaruh terhadap kesegaran jasmani siswa SMA Negeri 4 Semarang.

Kata Kunci: kesegaran jasmani, kecukupan vitamin a, kecukupan vitamin c, kecukupan zink, dan kadar hemoglobin

\section{PENDAHULUAN}

Kesegaran jasmani adalah kemampuan tubuh seseorang untuk melakukan tugas pekerjaan sehari-hari tanpa menimbulkan kelelahan yang berarti. $^{1}$ Menurut Sport Development Index (SDI) pada tahun 2006, hanya sebesar $1,08 \%$ masyarakat yang memiliki tingkat kesegaran baik sekali, 4,07\% tergolong baik, $13,55 \%$ termasuk kategori sedang, 43,90\% tergolong kurang bugar, dan $37,04 \%$ tergolong kurang sekali. ${ }^{2}$ Hasil penelitian secara nasional yang dilakukan Departemen Pendidikan Nasional (2006) menunjukkan bahwa kesegaran jasmani pada remaja hanya 5,29\% yang termasuk kategori baik sekali, baik sebesar $16,19 \%$, sedang sebanyak $29,99 \%$, kurang sebanyak $30,01 \%$ dan yang termasuk kategori kurang sekali $18,15 \%$. $^{3}$

Salah satu faktor yang mempengaruhi kesegaran jasmani adalah kadar hemoglobin. Hemoglobin mempunyai peran yang sangat penting dalam sirkulasi. ${ }^{4}$ Riset Kesehatan Dasar Nasional (2013) menunjukkan bahwa proporsi anemia di Indonesia mencapai $21,7 \%$ dimana untuk usia 15-24 tahun sebanyak 18,4\%, usia 25-34 tahun sebanyak 16,9\%, 35-44 tahun sebanyak $18,3 \%{ }^{5}$

Faktor lain yang juga mempengaruhi kesegaran jasmani adalah gizi. Gizi yang tepat untuk menunjang kesegaran jasmani anak terdiri dari makronutrien dan mikronutrien. Kebutuhan mikronutrien terdiri dari mineral dan vitamin. ${ }^{6}$ Zat gizi mikro adalah zat gizi yang dibutuhkan tubuh dalam jumlah kecil atau sedikit tetapi ada dalam makanan. Zat gizi yang termasuk kelompok ini adalah vitamin dan mineral, yang berfungsi sebagai pengatur proses metabolisme dalam tubuh. ${ }^{7}$

Hasil penjaringan kesehatan tingkat SMA/MA Dinas Kesehatan Kota Semarang Tahun 2016 menunjukkan bahwa kejadian ketidaksegaran jasmani paling banyak berada di wilayah Puskesmas Srondol. Dimana SMA Negeri 4 Semarang menjadi urutan pertama kejadian ketidaksegaran jasmani yaitu sebesar $94,74 \%{ }^{8}$

Tujuan dari penelitian ini adalah mendeskripsikan hubungan kecukupan vitamin $A$, vitamin C, zink dan kadar hemoglobin dengan kesegaran jasmani siswa SMA Negeri 4 Semarang. METODE

Penelitian ini dilakukan di SMA Negeri 4 Semarang bulan April - Mei 2017. Penelitian ini termasuk dalam bidang gizi klinik dan merupakan penelitian deskriptif analitik dengan rancangan cross sectional. Populasi yang terjangkau dalam penelitian ini adalah seluruh siswa kelas $X$ yaitu sebanyak 432 orang. Berdasarkan perhitungan besar sampel dengan menggunakan rumus Lameshow diperoleh besar sampel sebanyak 104 orang. Kriteria sampel dalam penelitian ini adalah bersedia untuk ikut serta dalam penelitian, bersedia hadir dalam pengambilan data dan menjawab pertanyaan pewawancara dan dalam keadaan sehat atau tidak sakit menurut pengakuan responden. Sampel penelitian diambil dengan menggunakan metode proportional stratified sampling, yaitu sampel dipilih dari populasi dan besar peluang setiap anggota populasi untuk menjadi sampel sama besar, yang dipilih secara acak sebanyak 104 siswa kelas X. Sampel yang yang tidak memenuhi kriteria inklusi akan dikeluarkan dan tidak digunakan.

Variabel dependent penelitian ini adalah kesegaran jasmani, variabel independent yaitu kecukupan vitamin A, kecukupan vitamin C, kecukupan zink dan kadar hemoglobin. Data kesegaran jasmani deperoleh dengan dengan Beep Test dan dinyatakan dengan level berdasarkan shuttle (jumlah lari bolak - balik) dalam satu menit dinyatakan dalam satuan $\mathrm{ml} / \mathrm{kgBB} /$ menit. Data kecukupan vitamin $A$, vitamin $C$ dan zink diperoleh dari hasil wawancara asupan makan dengan metode Food Recall selama 2 × 24 jam tidak berurutan kemudian diolah menggunakan Nutrisurvey. Hasil analisis Recall kemudian dirata rata dan dibandingkan dengan Angka Kecukupan Gizi (AKG) 2013 untuk Indonesia kemudian dikali $100 \%$ dinyatakan dalam persen. Data kadar hemoglobin didapatkan dengan menggunakan metode sianmethemoglobin dan dinyatakan dengan satuan $\mathrm{g} / \mathrm{dl}$. 
Uji kenormalan dan deskriptif data dilakukan dengan menggunakan uji KolmogorovSmirnov menunjukkan data terdistribusi tidak normal, maka digunakan uji Rank Spearman untuk menguji hubungan antara variabel yang diteliti. Untuk menguji variabel pengaruh (independent) yaitu kecukupan vitamin $A$, kecukupan vitamin C, kecukupan zink dan kadar $\mathrm{Hb}$ yang paling berpengaruh terhadap variabel terpengaruh (dependent) yaitu kesegaran jasmani menggunakan uji logistik regresi.

\section{HASIL DAN PEMBAHASAN}

\section{A. Gambaran Umum Lokasi Penelitian}

SMA Negeri 4 Semarang adalah SMA yang dijadikan lokasi dalam penelitian ini. Sarana prasarana yang ada di SMA Negeri 4 Semarang sudah termasuk baik dan dapat membatu menunjang seluruh kegiatan belajar mengajar. Ketersediaan kantin di SMA Negeri 4 Semarang juga sudah cukup baik. Terdapat beberapa penjual yang menyediakan berbagai jenis makanan dan minuman bagi para siswa. Makanan tersebut bervariasi mulai dari makanan ringan, snack, sampai makanan utama seperti bakso, nasi goreng, ayam geprek, mie rebus, mie goreng dan lain lain. Minuman yang disediakan juga beraneka ragam dari jus buah, es teh, minuman botol dan lain lain.

\section{B. Gambaran Sampel Penelitian}

Pada penelitian ini melibatkan 104 siswa kelas X SMA Negeri 4 Semarang. Sampel terdiri dari siswa laki - laki dan perempuan siswa terbanyak berjenis kelamin perempuan yaitu sebanyak 62 siswa (59\%) sedangkan siswa laki - laki sebanyak 42 siswa $(40,4 \%)$. Sedangkan umur siswa rata - rata adalah 15 16 tahun dengan persentase yang sama yaitu sebesar $49 \%$.

\section{Analisis Univariat}

\section{Tingkat Kesegaran Jasmani}

Tabel 1. Tingkat Kesegaran Jasmani Siswa SMA Negeri 4 Semarang

\begin{tabular}{llll}
\hline \multicolumn{1}{c}{ Variabel } & Rata-rata \pm SD & Minimum & Maksimum \\
\hline $\begin{array}{l}\text { Tingkat Kesegaran } \\
\text { (ml/kgBB/menit) }\end{array}$ & & & \\
\hline
\end{tabular}

Hasil penelitian diperoleh rata rata tingkat kesegaran jasmani adalah $31,99 \mathrm{ml} / \mathrm{kgBB} / \mathrm{menit}$ dengan standar deviasi $\pm 7,89$. Tingkat kesegaran jasmani minimum adalah $22,8 \mathrm{ml} / \mathrm{kgBB} /$ menit. Tingkat kesegaran jasmani maksimum adalah 54,5 ml/kgBB/menit.

Tabel 2. Distribusi Sampel menurut Kategori Tingkat Kesegaran Jasmani

\begin{tabular}{lcc}
\hline \multicolumn{1}{c}{ Kategori Kesegaran Jasmani } & N & $\%$ \\
\hline Sangat Kurang & 36 & 34.6 \\
Kurang & 7 & 6.7 \\
Cukup & 48 & 46.2 \\
Baik & 9 & 8.7 \\
Sangat Baik & 4 & 3.8 \\
Total & 104 & 100.0
\end{tabular}

Berdasarkan tabel 2 dapat dilihat bahwa tingkat kesegaran jasmani sampel paling dominan yaitu kategori cukup sebesar 46,2\%, kategori sangat kurang sebesar $34,6 \%$, dan kategori baik sebesar $8,7 \%$.

\section{Kecukupan Vitamin A}

Tabel 3. Persen Kecukupan Vitamin A Siswa SMA Negeri 4 Semarang

\begin{tabular}{cccl}
\hline Variabel & Rata-rata \pm SD & Minimum & Maksimum \\
& & & \\
\hline Persen kecukupan vitamin A (\%) & $146,19 \pm 88,03$ & 34,56 & 517,43
\end{tabular}

Hasil penelitian diperoleh rata rata persen kecukupan vitamin A siswa adalah 146,19 \% dengan standar deviasi $\pm 88,03$. Persen kecukupan vitamin A maksimum siswa adalah 517,43\%. Persen kecukupan vitamin A minimum siswa adalah $34,56 \%$. Data persen kecukupan vitamin A secara keseluruhan berdistribusi tidak normal dengan $p$ value 0,000 .

Tabel 4. Distribusi Sampel Menurut Kategori Kecukupan Vitamin A

\begin{tabular}{lcc}
\hline \multicolumn{1}{c}{ Kategori Kecukupan Vitamin $\mathbf{A}$} & $\mathbf{n}$ & $\%$ \\
\hline Kurang & 22 & 21.2 \\
Cukup & 82 & 78.8 \\
\hline Total & 104 & 100.0
\end{tabular}

Berdasarkan tabel 4 dapat dilihat bahwa kecukupan vitamin A sampel dengan kategori cukup sebesar 78,8\% dan dengan kategori kurang sebesar $21,2 \%$.

\section{Kecukupan Vitamin C}


Tabel 5. Persen Kecukupan Vitamin C Siswa SMA Negeri 4 Semarang

\begin{tabular}{ccll}
\hline Variabel & Rata-rata \pm SD & Minimum & Maksimum \\
& & & \\
\hline Persen kecukupan vitamin C (\%) & $53,22 \pm 89,78$ & 1,33 & 734,17
\end{tabular}

Hasil penelitian diperoleh rata rata persen kecukupan vitamin C siswa adalah 53,22\% dengan standar deviasi $\pm 89,78$. Persen kecukupan vitamin A maksimum siswa adalah $734,17 \%$. Persen kecukupan vitamin C minimum siswa adalah $1,33 \%$. Data persen kecukupan vitamin $\mathrm{C}$ secara keseluruhan berdistribusi tidak normal dengan $\mathrm{p}$ value 0,000 .

Tabel 6. Distribusi Sampel Menurut Kategori Kategori Kecukupan Vitamin C

\begin{tabular}{lcc}
\hline \multicolumn{1}{c}{ Kategori Kecukupan Vitamin C } & $\mathbf{n}$ & $\%$ \\
\hline Kurang & 89 & 85.6 \\
Cukup & 15 & 14.4 \\
\hline Total & 104 & 100.0 \\
\hline
\end{tabular}

Berdasarkan tabel 6 dapat dilihat bahwa kecukupan vitamin C sampel dengan kategori kurang sebesar 85,6\% dan dengan kategori cukup sebesar $14,4 \%$.

4. Kecukupan Zink

Tabel 7. Persen Kecukupan Zink Siswa SMA Negeri 4 Semarang

\begin{tabular}{ccll}
\hline Variabel & Rata-rata \pm SD & Minimum & Maksimum \\
& & & \\
\hline Persen kecukupan zink (\%) & $36,82 \pm 11,07$ & 15,33 & 75,00
\end{tabular}

Hasil penelitian diperoleh rata rata persen kecukupan zink siswa adalah $36,82 \%$ dengan standar deviasi $\pm 11,07$. Persen kecukupan zink minimum siswa adalah 15,33\%. Persen kecukupan zink maksimum siswa adalah 75,00\%. Data persen kecukupan zink secara keseluruhan berdistribusi tidak normal dengan $\mathrm{p}$ value 0,008 .

Tabel 8. Distribusi Sampel Menurut Kategori Kategori Kecukupan Zink

\begin{tabular}{ccc}
\hline Kategori Kecukupan Zink & N & $\%$ \\
\hline Kurang & 104 & 100.0 \\
\hline
\end{tabular}

Berdasarkan tabel 8 dapat dilihat bahwa $100 \%$ sampel memiliki kecukupan zink dengan kategori kurang.

\section{Kadar Hemoglobin}

Tabel 9. Kadar Hemoglobin Siswa SMA Negeri 4 Semarang

\begin{tabular}{ccll}
\hline Variabel & Rata-rata \pm SD & Minimum & Maksimum \\
\hline Kadar Hemoglobin (g\%) & $13,25 \pm 1,61$ & 8,00 & 16,2 \\
\hline
\end{tabular}

Hasil penelitian diperoleh rata rata kadar hemoglobin adalah 13,25 g\% dengan standar deviasi $\pm 1,61$. Kadar hemoglobin minimum adalah 8,00 g\%. Kadar hemoglobin maksimum adalah 16,2 g\%. Data kadar hemoglobin secara keseluruhan berdistribusi normal dengan p value 0,2 .

Tabel 10. Distribusi Sampel Menurut Kadar Hemoglobin

\begin{tabular}{lcc}
\hline \multicolumn{1}{c}{ Kategori Kadar $\mathbf{H b}$} & $\mathbf{n}$ & $\%$ \\
\hline Normal & 75 & 72.1 \\
Kurang & 29 & 27.9 \\
Total & 104 & 100.0 \\
\hline
\end{tabular}

Berdasarkan tabel 10 dapat dilihat bahwa kadar hemoglobin sampel dengan kategori normal sebesar 72,1\% dan dengan kategori kurang sebesar $27,9 \%$.

\section{Analisis Bivariat}

1. Hubungan Kecukupan Vitamin A dengan Kesegaran Jasmani

Hasil analisis statistik menggunakan uji Rank Spearman tidak terdapat hubungan, dengan hasil analisis menunjukkan hubungan kecukupan vitamin A dengan tingkat kesegaran jasmani memiliki $p$-value $=0,788(p$-value $>0,05)$ dan koefisien korelasi $r=0,027$. Dapat disimpulkan bahwa tidak ada hubungan yang signifikan antara kecukupan vitamin A dengan tingkat kesegaran jasmani. Kecenderungan data 
pada penelitian ini dapat dilihat pada gambar 1.

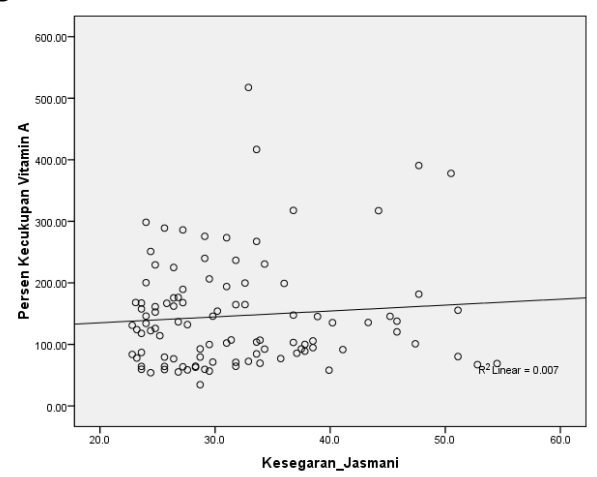

Gambar 1. Hubungan Kecukupan Vitamin A dengan Kesegaran Jasmani

Gambar 1. terlihat bahwa sebaran data mengarah pada kemiringan tertentu (terpola) ke arah kanan atas. Ada kecenderungan positif antara kecukupan vitamin A dengan tingkat kesegaran jasmani. Yaitu semakin tinggi kecukupan vitamin A maka semakin tinggi pula tingkat kesegaran jasmani dan semakin rendah kecukupan vitamin A maka semakin rendah pula tingkat kesegaran jasmani.

Defisiensi vitamin A dapat mempengaruhi performa aktifitas fisik vitamin A dalam keberadaan $\beta$-karoten di dalam tubuh berperan sebagai antioksidan yang berfungsi mereduksi kerusakan sel selama latihan karena radikal bebas yang membantu memperkuat daya tahan tubuh dalam meningkatkan aktivitas sel pembunuh kuman (natural killer cell) serta memproduksi limfosit dan antibody. ${ }^{9}$

$$
\text { Dalam penelitian tingkat }
$$
kecukupan vitamin A tidak terdapat hubungan yang bermakna dengan kesegaran jasmani secara statistik. Penelitian ini sejalan dengan penelitian yang dilakukan oleh Muizzah yang menyimpulkan bahwa tidak terdapat hubungan antara vitamin A dengan kesegaran jasmani. ${ }^{10}$

\section{Hubungan Kecukupan Vitamin $\mathrm{C}$ dengan Kesegaran Jasmani}

Vitamin C berfungsi untuk mereduksi besi menjadi feri dan menjadi fero dalam usus halus sehingga mudah untuk diabsorbsi. Dalam aktivitas, vitamin C berguna dalam stimulasi sistem imun, mengurangi kelelahan dan kelemahan otot, meningkatkan performa, dan melindungi sel dari ancaman radikal bebas. $^{9}$ Kekurangan vitamin C dapat mengakibatkan menurunnya daya tahan tubuh dan kontraksi otot melemah dan terjadi kelelahan. Gejala kekurangan vitamin C ditandai dengan kemunduran penampilan fisik. ${ }^{11}$

Hasil analisis statistik menggunakan uji Rank Spearman menyatakan bahwa tidak terdapat hubungan yang bermakna, dengan hasil analisis menunjukkan hubungan tingkat kecukupan vitamin $C$ dengan kesegaran jasmani memiliki $p$-value $=0,203(p$-value $>0,05)$ dan koefisien korelasi $r=-0,126$. Tidak terdapat hubungan yang signifikan antara tingkat kecukupan vitamin C dengan kesegaran jasmani siswa di SMA Negeri 4 Semarang. Kecenderungan data pada penelitian ini dapat dilihat pada gambar 2.

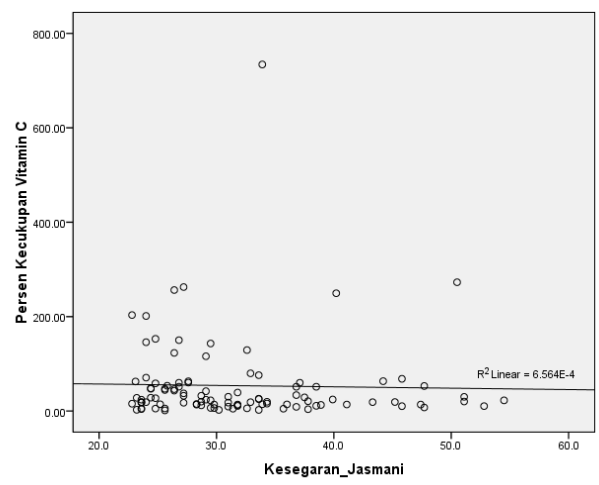

Gambar 2. Hubungan Kecukupan Vitamin C dengan Kesegaran Jasmani

Gambar 2. tidak terlihat bahwa sebaran data mengarah pada kemiringan tertentu (terpola). Sehingga tidak ada kecenderungan memiliki hubungan antara tingkat kecukupan vitamin C dengan kesegaran jasmani.

Penelitian ini sejalan dengan penelitian Halimah yang menyatakan bahwa tidak ada hubungan yang signifikan antara tingkat konsumsi vitamin $\mathrm{C}$ dengan skor tingkat kesegaran jasmani atlet ( $p>$ $0,05)$ pada atlet di Pusat Pendidikan dan Latihan Pelajar Jawa Tengah. ${ }^{12}$ 
Tingkat kesegaran jasmani seseorang dipengaruhi oleh berbagai faktor yaitu genetik, umur, jenis kelamin, aktivitas fisik, lingkungan, kesehatan badan dan keadaan gizi. ${ }^{13}$

3. Hubungan Kecukupan Zink dengan Kesegaran Jasmani

Hasil uji statistik menggunakan Rank Spearman menyatakan bahwa tidak terdapat hubungan yang bermakna, dengan hasil analisis menunjukkan hubungan kecukupan zink dengan tingkat kesegaran jasmani memiliki $p$-value = 0,257 ( $p$-value $>0,05$ ) dan koefisien korelasi $r=-0,122$. Dapat disimpulkan bahwa tidak ada hubungan yang signifikan antara kecukupan zink dengan tingkat kesegaran jasmani. Kecenderungan data pada penelitian ini dapat dilihat pada gambar 3.

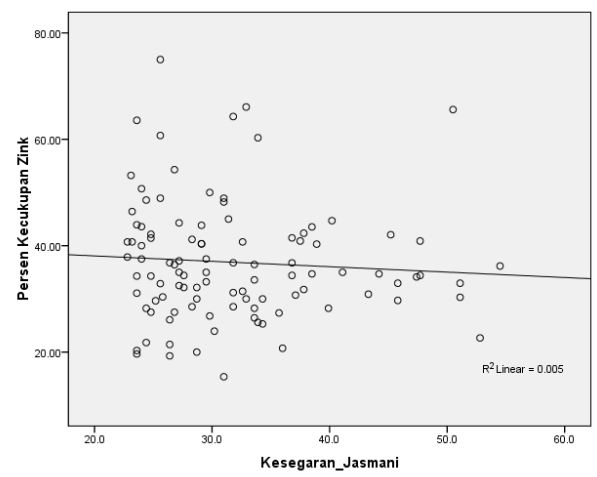

Gambar 3. Hubungan Kecukupan Zink dengan Kesegaran Jasmani

Berdasarkan gambar 3 terlihat bahwa ada kecenderungan negatif yaitu semakin tinggi kadar zink maka semakin rendah kesegaran jasmani dan semakin rendah kecukupan zink maka semakin tinggi kesegaran jasmani.

Status zink yang rendah dapat menghambat fungsi alat - alat tubuh yang berperan dalam mengoptimalkan kesegaran jasmani. Zink yang rendah mengakibatkan menurunnya konsentrasi zink serum yang berhubungan dengan rusaknya fungsi - sungsi otot, termasuk dalam menurunnya kekuatan dan meningkatnya kecenderungan untuk menjadi lelah dan turunnya tenaga selama puncak kerja, kemudian status zink yang rendah menyebabkan menurunnya fungsi fisik dan penampilan. ${ }^{14}$

Dalam penelitian ini tidak ditemukan hubungan yang bermakna antara kecukupan zink dan tingkat kesegaran jasmani. Usia remaja memiliki kebiasaan makan yang dipengaruhi oleh lingkungan, teman sebaya dan kehidupan sosial, dan kegiatan yang dilakukan di luar rumah. $^{15}$ Seluruh siswa yang menjadi sampel penelitian di SMA Negeri 4 Semarang memiliki kecukupan zink yang termasuk dalam kategori kurang berdasarkan hasil recall $2 \times 24$ jam.

Hasil penelitian ini sejalan dengan penelitian pada siswa SD di Tersobo yang juga tidak menunjukkan hubungan yang signifikan antara asupan zink dan dengan p-value 0,455 dengan kesegaran jasmani dihitung berdasarkan nilai berjalan 1 mil dengan metode food record. $^{16}$

\section{Hubungan Kadar Hemoglobin dengan Kesegaran Jasmani}

Hemoglobin di dalam sel darah merah memungkinkan darah untuk mengangkut 30 sampai 100 kali jumlah oksigen yang dapat ditransport dalam bentuk oksigen terlarut di dalam cairan darah (plasma). Makin tinggi kadar hemoglobin, proses transport oksigen ke jaringan akan makin optimal sehingga mempengaruhi nilai VO2 maks. ${ }^{17}$

Hasil uji statistik menggunakan Rank Spearman menyatakan bahwa terdapat hubungan yang bermakna, dengan hasil analisis menunjukkan hubungan kadar hemoglobin dengan tingkat kesegaran jasmani memiliki $p$ value $=0,000(p$-value $<0,05)$ dengan koefisien korelasi $r=0,509$. Pada penelitian ini dapat disimpulkan bahwa ada hubungan yang signifikan antara kadar hemoglobin dengan tingkat kesegaran jasmani. Kecenderungan data pada penelitian ini dapat dilihat pada gambar 4 . 


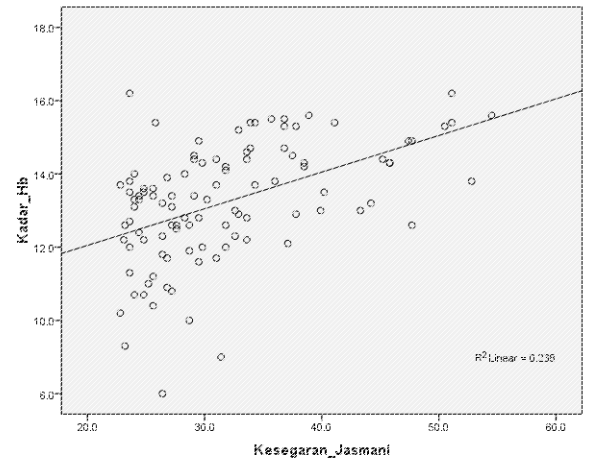

Gambar 4. Hubungan Kadar Hemoglobin dengan Kesegaran Jasmani

Gambar 4. terlihat bahwa sebaran data mengarah pada kemiringan tertentu (terpola) ke arah kanan atas. Ada kecenderungan positif bahwa semakin tinggi kadar hemoglobin maka semakin tinggi pula kesegaran jasmaninya, dan semakin rendah kadar hemoglobin maka semakin rendah pula kesegaran jasmaninya.

Hemoglobin berperan dalam pengangkutan oksigen. Hemoglobin cenderung mengikat oksigen dengan lingkungan yang memiliki kadar oksigen tinggi dan melepaskan oksigen dalam lingkungan dengan kadar oksigen relatif lebih rendah. Dengan demikian hemoglobin mengambil oksigen dalam paru - paru dan melepasnya ke jaringan yang aktif, seperti otot yang berkontraksi. Kecepatan dan volume pemakaian oksigen maksimal dikenal dengan VO2max. ${ }^{18}$

Hal tersebut sesuai dengan penelitian Ohira, yang mengungkapkan bahwa VO2 maks berhubungan secara signifikan dengan kadar $\mathrm{Hb}$, dan VO2 maks lebih rendah pada subjek penelitian yang anemia dibandingkan dengan subjek penelitian yang normal. ${ }^{19}$

Sebuah penelitian yang dilakukan Cendani pada 30 remaja putri menyatakan bahwa kadar $\mathrm{Hb}$ mempengaruhi tingkat kesegaran jasmani. ${ }^{20} \mathrm{Hal}$ ini sejalan dengan Novita yang menunjukkan hubungan positif $68,72 \%$ antara kadar hemoglobin dengan kapasitas aerobik pada Atlet Wushu Prima tahun $2014 .^{21}$

\section{E. Anlisis Multivariat}

Tabel 11. Hasil Analisis Anova pada Regresi Linier Ganda antara Kecukupan Vitamin A, Kecukupan Vitamin C, Kecukupan Zink dan Kadar Hemoglobin dengan Tingkat Kesegaran Jasmani

\begin{tabular}{|c|c|c|c|c|c|}
\hline Sumber Keragaman & $\begin{array}{l}\text { Sum of } \\
\text { Squares }\end{array}$ & df & $\begin{array}{c}\text { Mean } \\
\text { Square }\end{array}$ & $\mathbf{F}$ & p value \\
\hline $\begin{array}{l}\text { Kecukupan Vitamin A, } \\
\text { Kecukupan Vitamin C, } \\
\text { Kecukupan Zink dan Kadar } \\
\text { Hemoglobin }\end{array}$ & 1575.998 & 4 & 393.999 & 8.107 & $.000^{\mathrm{a}}$ \\
\hline $\begin{array}{l}\text { Faktor lain } \\
\text { Femogin }\end{array}$ & 4762.813 & 98 & 48.600 & & \\
\hline Total & 6338.810 & 102 & & & \\
\hline
\end{tabular}

Dari tabel 11 tampak bahwa variabel kecukupan vitamin A, kecukupan vitamin C, kecukupan zink dan kadar hemoglobin secara simultan berhubungan yang bermakna dengan tingkat kesegaran jasmani dengan $p$ value $=0,000$. Dari angka Sum of Squares dapat dihitung besar hubungan variabel variabel kecukupan vitamin $A$, kecukupan vitamin C, kecukupan zink dan kadar hemoglobin dengan tingkat kesegaran jasmani sebesar 24,86\%. Hasil Korelasi Regrei Linier Ganda antara kecukupan vitamin A, kecukupan vitamin $\mathrm{C}$, kecukupan zink dan kadar hemoglobin dengan tingkat kesegaran jasmani dapat dilihat pada tabel 12 .

Tabel 12. Hasil Korelasi Regresi Linier Ganda antara Kecukupan Vitamin A, Kecukupan Vitamin C, Kecukupan Zink dan Kadar Hemoglobin dengan Tingkat Kesegaran Jasmani

\begin{tabular}{lccc}
\hline \multirow{2}{*}{ Variabel Independen } & \multicolumn{3}{c}{ Koefisien Regresi } \\
\cline { 2 - 4 } & $\begin{array}{c}\text { Tidak } \\
\text { Terstandarisasi }\end{array}$ & Terstandarisasi & p value \\
\hline (Constant) & .899 & & .888 \\
Kecukupan Vitamin A & .007 & .083 & .368 \\
Kecukupan Vitamin C & -.005 & -.056 & .548 \\
Kecukupan Zink & -.032 & -.045 & .640 \\
Kadar Hemoglobin & 2.369 & .485 & .000 \\
\hline
\end{tabular}

Berdasarkan tabel 12 dapat dilihat bahwa setiap kenaikan persen kecukupan vitamin A menaikkan kesegaran jasmani sebesar 0,007 kenaikan tersebut tidak bermakna dengan $\mathrm{p}$-value $=0,368$, setiap kenaikan persen kecukupan vitamin $C$ menurunkan kesegaran jasmani sebesar 0,005 penurunan tersebut tidak bermakna dengan $p$-value $=0,548$, setiap kenaikan persen kecukupan zink menurunkan kesegaran jasmani sebesar 0,007 penurunan tersebut tidak bermakna dengan $\mathrm{p}$-value = 0,640, dan setiap kenaikan $1 \mathrm{gr} \%$ kadar 
hemoglobin menaikkan kesegaran jasmani sebesar 2,369 dan merupanan kenaikan yang bermakna dengan $\mathrm{p}$-value $=0,000$.

Dari angka koefisien regresi terstandarisasi, diantara empat variabel yaitu kecukupan vitamin A, kecukupan vitamin C, kecukupan zink dan kadar hemoglobin, yang mempunyai pengaruh yang paling besar dengan kesegaran jasmani adalah kadar hemoglobin dengan angka koefisien paling besar.

\section{KESIMPULAN}

1. Ada hubungan yang signifikan antara kadar hemoglobin ( $p$-value $=0,000) \quad$ dengan kesegaran jasmani siswa di SMA Negeri 4 Semarang.

2. Kadar hemoglobin merupakan faktor yang paling berpengaruh terhadap kesegaran jasmani siswa SMA Negeri Semarang.

\section{SARAN}

\section{Bagi Siswa}

Meningkatkan asupan makanan sumber vitamin (vitamin A dan Vitamin C) dan mineral (zink) seperti sayuran dan buah buahan dan meningkatkan variasi jenis makanan yang dikonsumsi.

\section{Bagi Sekolah}

Memberikan penyuluhan kepada siswanya tentang pentingnya meningkatkan asupan makanan sumber vitamin dan mineral. Disamping itu juga meningkatkan kualitas kantin yang sudah ada dengan variasi makanan sumber vitamin dan mineral lebih ditingkatkan.

\section{DAFTAR PUSTAKA}

1. Hantoro, Budi. Ketahuilah Kesegaran Jasmani Anda. Pusat Pengembangan Kualitas Jasmani. Jakarta: 2003. 45

2. Kementrian Pemuda dan Olahraga Republik Indonesia. Rencana Strategis Kementrian Pemuda dan Olahraga Tahun 2010 - 2014. Kementrian Pemuda dan Olahraga Republik Indonesia. Jakarta: 2010

3. Departemen Pendidikan Nasional. Pembelajaran Pengembangan Kebugaran
Jasmani Sekolah Menengah Atas (SMA). Departemen Pendidikan Nasional. Jakarta: 2006

4. Abdul. Darah. Pustaka Pelajar. Yogyakarta: 2002

5. Badan Penelitian dan Pengembangan Kesehatan Kementerian Kesehatan RI. RISET KESEHATAN DASAR (RISKESDAS 2013). Kementerian Kesehatan Republik Indonesia: Jakarta, 2013

6. Zulaekah, S. and Hastuti, N.P., Hubungan Tingkat Konsumsi Karbohidrat, Protein Dan Lemak Dengan Kesegaran Jasmani Anak Sekolah Dasar di SD N Kartasura I. Surakarta, 2009.

7. Almatsier, S. Prinsip Dasar Ilmu Gizi. PT Gramedia Pustaka Utama: Jakarta, 2004.

8. Dinas Kesehatan Kota Semarang. Hasil Penjaringan Kesehatan Tingkat SMA/MA Tahun 2016. Dinas Kesehatan Kota Semarang: Semarang, 2016.

9. Cintya FH. Hubungan Tingkat Kecukupan Zink dan Vitamin A dengan Kesegaran Jasmani Atlet Sepakbola di Arunajaya Football Academy Kota Salatiga. Skripsi. 2016

10. Muizzah, L. Hubungan antara Kebugaran dengan Status Gizi dan Aktivitas Fisik pada Mahasiswa Program Studi Kesehatan Masyarakat UIN Syarif Hidayatullah Jakarta Tahun 2013. Skripsi Program Studi Kesehatan Masyarakat Fakultas Kedokteran dan IImu Kesehatan Universitas Islam Negeri Syarif Hidayatullah: Jakarta, 2013.

11. Williams, Robert, M. Nutrition, Health and Fitness. New York, USE: McGrawHill. 2002.

12. Halimah N, Rosidi A, SU YN. Hubungan Konsumsi Vitamin C Dengan Kesegaran Jasmani Pada Atlet Sepakbola di Pusat Pendidikan dan Latihan Olahraga Pelajar Jawa Tengah. Jurnal Gizi. 2014;3(2).

13. Abdullah. Kesegaran Jasmani. Departemen Kesehatan Republik Indonesia: Jakarta, 1994.

14. Ramayulis, Rita. Gizi Kebugaran (Nutrition for Fitness), dalam Pelatihan Gizi Olahraga. 3-5 April 2008.

15. Almatsier, S. Gizi Seimbang Dalam Daur Kehidupan. PT Gramedia Pustaka Utama: Jakarta, 2011.

16. Iskaningtyas, Dita Anitya. Model Prediksi VO2max anak usia 10-11 tahun Etnis Jawa (Desa Tersobo, Kebumen) dari Tes Berjalan 1 mil Berdasarkan Jenis Kelamin, Denyut Nadi dan Waktu Tempuh. Skripsi: Depok, 2011.

17. Hall JE. Guyton and Hall Textbook of Medical Physiology. Saunders Elsevier: USA, 2010. Edisi ke-12. 
18. Widiastuti, Putu Ayu, Dkk. 2009. Pola Makan Dan Kebugaran Jasmani Atlet Pencak Silat Selama Pelatihan Daerah Pekan Olahraga Nasional XVII Provinsi Bali Tahun 2008. Jurnal Gizi Klinik Indonesia 2009 Vol. VI (1) Hal 13-20

19. Ohira, Y., Koziol, B.J., Edgerton, V.R. and Brooks, G.A., Oxygen consumption and work capacity in iron-deficient anemic rats. The Journal of nutrition, 111(1), pp.17-25. 1981.
20. Cendani, C, Murbawani E. A. Asupan Mikronutrien, Kadar Hemoglobin dan Kesegaran Jasmani Remaja Putri. 2011

21. Novita N. Hubungan Kadar Hemoglobin terhadap Kapasiti Aerobik (Studi Korelasi pada Atlet Wushu Prima 2014). Jurnal Pengabdian Kepada Masyarakat. 2015 Mar 1;21(79):73-7 